\title{
Stakeholder-Associated Factors Influencing Construction and Demolition Waste Management: A Systematic Review
}

\author{
Xianbo Zhao \\ School of Engineering and Technology, Central Queensland University, Sydney Campus, 400 Kent Street, \\ Sydney, NSW 2000, Australia; b.zhao@cqu.edu.au
}

check for updates

Citation: Zhao, $\mathrm{X}$

Stakeholder-Associated Factors

Influencing Construction and

Demolition Waste Management: A

Systematic Review. Buildings 2021, 11, 149. https://doi.org/10.3390/

buildings 11040149

Academic Editors: Wahidul Biswas,

Chyi Lin Lee, Samad M.

E. Sepasgozar and Lan Ding

Received: 8 March 2021

Accepted: 29 March 2021

Published: 2 April 2021

Publisher's Note: MDPI stays neutral with regard to jurisdictional claims in published maps and institutional affiliations.

Copyright: (c) 2021 by the author Licensee MDPI, Basel, Switzerland. This article is an open access article distributed under the terms and conditions of the Creative Commons Attribution (CC BY) license (https:// creativecommons.org/licenses/by/ $4.0 /)$

\begin{abstract}
Construction and demolition (C\&D) activities generate a large amount of waste and have significant impacts on the environment. Thus, it is necessary to implement C\&D waste management (WM), which requires the involvement of stakeholders and is influenced by a variety of factors. This study aims to undertake a systematic review of the stakeholder-associated factors influencing C\&D WM. The Scopus search engine was used in a literature search, and two rounds of screening were performed. Only journal articles or reviews that were published in English after 2000 were used in this study. A total of 106 journal articles were reviewed. The review identified 35 stakeholder-associated factors influencing C\&D WM and categorized them into six groups: regulatory environment, government and public supervision, advances in technologies, recycling market, knowledge, awareness, attitude, and behaviour of stakeholders, and project-specific factors. All the 35 factors are discussed in detail with considerations into relevant stakeholders. Although there have been studies focused on the factors influencing C\&D WM, few have attempted to take stakeholders' perspectives into consideration. This study expands the C\&D WM literature by mapping the influential factors with relevant stakeholders and enables the practitioners to clearly understand their roles and responsibilities and make better informed decisions in the C\&D WM process.
\end{abstract}

Keywords: stakeholder; construction; demolition; waste management; factor

\section{Introduction}

The construction industry has been widely recognized as a major consumer of natural resources and energy and generates great quantities of construction and demolition (C\&D) waste $[1,2]$. Demolition waste is the waste that arises from razed structures, while construction waste refers to the waste from construction, renovation, and repairing of individual premises, commercial buildings, and other types of buildings [3]. C\&D waste consists of inert and non-inert materials [4]. The inert portion is comprised of soft inert materials (e.g., soil and slurry) and hard inert materials (e.g., masonry and concrete), while the noninert portion includes materials such as plastics, glass, timber, paper, and organic materials. Some C\&D waste contains hazardous substances, such as lead paint, contaminated soils, and asbestos from demolished structures. Thus, it is necessary to segregate C\&D waste at source $[5,6]$.

C\&D waste was estimated to represent $36 \%$ of the total waste generation in the membership countries of the Organisation for Economic Co-operation and Development (OECD) [7]. The European Union (EU) produced 834 million tonnes of C\&D waste, which represented the largest proportion (36\%) of the total waste in 2018 [8]. Australia generated 20.4 million tonnes of C\&D waste in 2016-2017, representing approximately $30.5 \%$ of the total waste [9]. This indicated an increase of $20 \%$ in Australian C\&D waste generation in the past decade. Brazil was estimated to produce 100 million tonnes of C\&D waste in 2016 [10]. China has experienced rapid urbanization and a huge amount of infrastructure construction in the past decades and has become the largest C\&D waste producer. In 2019, China was estimated to generate approximately 2.3 billion tonnes of C\&D waste [11], which was much higher than the 600 million tonnes in the USA [12]. 
The huge amount of C\&D waste tends to occupy huge landfill spaces and exert harmful impacts on the environment, if not properly treated. Therefore, effective C\&D waste management $(\mathrm{WM})$ practice has been widely advocated and promoted around the world. C\&D WM has incorporated the concepts of the $3 R$ (i.e., reduce, reuse, and recycle) principle and the circular economy [13-15]. These concepts are consistent with the five major steps (i.e., reduce, reuse, recycle, recover, and disposal) in the WM framework proposed by El-Haggar [16]. Effective C\&D WM is likely to bring about benefits to relevant stakeholders, such as cost saving, reduced demand for landfill spaces, fewer accidents, better social image, and improved productivity [16,17].

Although it is believed that around $90 \%$ of C\&W waste is recyclable [6], previous studies indicated that at least $35 \%$ of the global C\&D waste was still directly sent to landfill sites without treatment [18]. Developed countries tend to have a higher recycling and reuse rate [19]. For instance, Australia recycled 67\% of the C\&D waste in 2017 [9]; the EU member countries, such as the Netherlands, Germany, Denmark, and the UK, achieved a recycling rate of $80-90 \%$ [18] and a near zero landfilling [13]; and Japan and South Korea have made great efforts to achieve a reuse rate of $97 \%$ [20]. However, in emerging economies or developing countries, there is still much room to improve their recycling and reuse rate due to the lack of recycling facilities and relevant technologies. For example, previous studies have estimated the recycling rate in Mainland China to be only 5-10\% [15,21,22]; and India recycles only 1\% of its C\&D waste [23]. This fact echoes the prediction of Yuan and Shen [24] that C\&D WM would be a practical issue in developing countries.

C\&D WM is obviously an interdisciplinary research field, covering management, engineering, technology, economic, and policy research and targeting environmental, social, and economic sustainability [2]. C\&D WM practice is influenced by various factors. The factors with positive influences on C\&D WM can be seen as drivers or facilitators, while those with negative effects on C\&D WM can be viewed as barriers. In the past decade, previous empirical studies have identified a list of such drivers and/or barriers in a region or country, such as Mainland China [25,26], Hong Kong [27], Australia [28], the UK [29], and Thailand [30].

Effective C\&D WM inevitably requires the participation of various stakeholders [31,32]. These stakeholders refer to the organizations or individuals that are involved in C\&D WM. Different stakeholders tend to have different roles, concerns, and goals [33], which result in in different behaviours, awareness, and attitudes [34] and make it challenging to implement C\&D WM [35]. For example, governments and the public tend to be concerned about the enforcement of regulations and policies, as well as social and environmental impacts of C\&D WM [36,37]; clients may pay more attention to economic viability [28]; designers tend to be passive about $C \& D$ WM because they believe $C \& D$ waste is usually generated in the construction phase, but not the design phase [38,39]; contractors usually emphasize cost and time savings $[30,40]$ and play a crucial role in reducing or minimizing C\&D waste on site; waste recycling companies emphasize the government subsidy and sales revenues [37]; and experts or researchers tend to be concerned about development and use of relevant technologies.

The roles of multiple stakeholders have attracted attention from researchers in the area of C\&D WM. For instance, Shen et al. [41] examined the decision-making behaviour of material manufacturers and contractors in the $\mathrm{C} \& \mathrm{D}$ waste recycling process under various environmental regulations; Su et al. [37] investigated the Chinese C\&D waste recycled product market and argued that the central and local governments, contractors, and waste recycling companies could be viewed as promoters, supervisors, purchasers, and producers in this market, respectively; and Du et al. [36] undertook evolutionary game analysis of the decision-making behaviour of governments, the public, and contractors in C\&D WM. However, few studies have attempted to provide a stakeholder perspective on the factors influencing C\&D WM.

The stakeholders engaged in the C\&D WM process should be clear about their roles $[14,42]$. The factors influencing C\&D WM should be linked to specific stakeholders, 
which allows the stakeholders to clearly understand their roles and responsibilities and make better informed decisions in the C\&D WM process. Therefore, the research question of this study is: What are the stakeholder-associated factors that influence CED WM? To address this research question, this study aims to undertake a systematic review of the factors influencing C\&D WM with a stakeholder perspective. This study identifies a comprehensive list of the factors influencing C\&D WM and undertakes mapping between the factors and relevant stakeholders through a systematic literature review.

\section{Previous Review Work}

Literature review refers to a more or less systematic approach to collecting and synthesising previous research [43,44]. A literature review sets up a solid foundation for driving theory development and advancing knowledge [45] and helps to obtain an in-depth understanding of a specific research field $[2,46]$. The C\&D WM research field has a large number of literature reviews published in journals. Some focus on a single aspect of C\&D WM research (e.g., [47]), while some take a holistic view (e.g., [2]).

There have been several reviews focused on C\&D WM practice in specific countries, such as India [48], Egypt [49], Norway [50], Malaysia [51], Russia [52], and China [53]. These reviews have mostly reported the regulations and policies, managerial implications, and challenges relating to the C\&D WM practice in these countries.

The technologies to recycle and reuse C\&D waste have attracted great attention, and there have been several reviews discussing the development of the technologies to recycle a single type of material, such as concrete [54], wood [55], and glass [56]. In addition, Tam and Tam [57] undertook a comprehensive review of the recycling practices of ten materials, whilst Sormunen and Kärki [58] reviewed the possibilities of using nine types of recycled materials as raw components for composite materials. In addition, information technology can improve the efficiency of C\&D WM. Li et al. [47] reviewed the application of eight advanced information and communication technologies (ICTs) in C\&D WM, including building information modelling (BIM), big data, barcode technology, radio frequency identification (RFID), image recognition technology, image analysis, global positioning system (GPS), and geographic information system (GIS).

Additionally, some reviews took a holistic view of the global C\&D WM research. For example, Yuan and Shen [24] analysed journal publications in 2000-2009 and predicted an increasing use of modelling and simulating techniques in C\&D WM practice; Wu et al. [59] used a bibliometric analysis of the relevant journal publications in 1994-2017 and detected five research clusters, including environmental concerns, recyclability of C\&D waste, performance and behavioural tests of recycled products, C\&D WM practice, and C\&D waste with industrial ecology; and Jin et al. [2] undertook a scientometric analysis of the journal articles published in 2009-2018 and discussed the hot research themes, research gaps, and future research directions.

There have been few reviews focused on the factors influencing C\&D WM practice. Kabirifar et al. [14] made a good attempt to review the factors contributing to effective C\&D WM with considerations into the $3 R$ principle but failed to identify the relationship between stakeholders and factors. Therefore, this study aims to undertake a systematic review of the factors influencing C\&D WM and link the factors to the relevant stakeholders.

\section{Methodology}

This study undertook a systematic review of the previous publications relating to C\&D WM. A systematic literature review can be seen as a research method to synthesize all relevant research findings that fit pre-defined inclusion criteria to address a particular research question [44].

There are at least three types of inclusion criteria. The first type is to select the databases to be searched for publications; the second type is to combine search terms and logical connectors to identify a manageable set of publications from the selected database; and the third type is to guide selection of publications for analysis [60]. These inclusion 
criteria should be guided by the research question and objectives. Figure 1 show the literature review methodology.

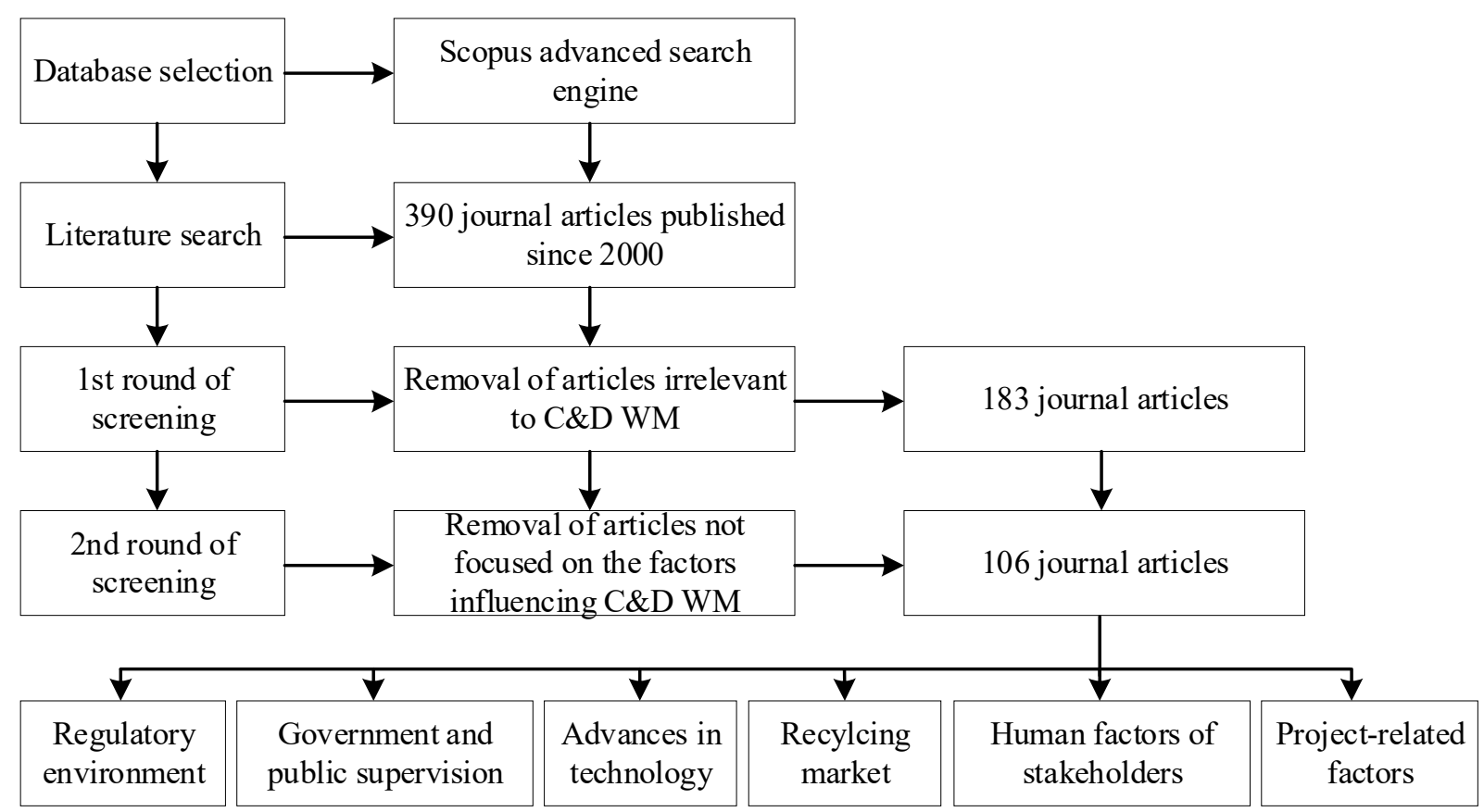

Figure 1. The review process.

\subsection{Database Selection}

There are several general databases that can be searched for publications, such as PubMed, Google Scholar, Scopus, and Web of Science. Comparing between various databases, Falagas et al. [61] found that Google Scholar produced results of inconsistent accuracy and that Scopus had wider coverage of journals than Web of Science and was strong in keyword search and citation analysis. In addition, Scopus has been widely used in review articles in the construction management area $[2,62]$. Therefore, Scopus was selected to search relevant publications in this study.

\subsection{Literature Search}

The terms "construction", "demolition", "building", "waste", and "C\&D" represented C\&D waste in the retrieval code. The terms "factor", "enabler", "driver", "facilitator", "barrier", "obstacle", and "hindrance" represented the influential factors in the retrieval code. In addition, the terms "management", "recycling", "reduction", and "minimizing" denoted WM practice in the retrieval code. The term "stakeholder" was not included in the retrieval code because few studies have linked the factors to stakeholders, and inclusion of "stakeholder" produced a small number of publications. Additionally, only journal articles or reviews that were published in English after 2000 were used in this study. This is because journal articles are recognized as representative of the most influential and reputable research $[63,64]$, and most systematic literature reviews use only journal publications $[65,66]$. The initial search process started from inputting the following retrieval code in the advanced search engine of Scopus:

TITLE (construction OR demolition OR building OR C\&D AND waste) AND TITLEABS-KEY(manag* OR reduc* OR recycl* OR minimi*) AND TITLE-ABS-KEY(driv* OR motivat ${ }^{*}$ OR enabl ${ }^{*}$ OR facilitat ${ }^{*}$ OR obstacle OR barrier OR hinder* OR hindrance OR factor) AND PUBYEAR > 1999 AND (LIMIT-TO (DOCTYPE, “ar") OR LIMIT-TO (DOCTYPE, "re")) AND (LIMIT-TO (LANGUAGE, “English")). 
The character " **" enables a fuzzy search to identify variations of a term. The initial search generated a preliminary list of 390 literatures in early 2021, which were sorted by relevance in Scopus. It should be noted that these 390 literatures included the articles in-press, which may be officially published in 2021 or later.

\subsection{Screening}

Two rounds of screening were undertaken in this study to identify the most relevant literatures for further analysis. In the first round of screening, the articles closely relating to $C \& D W M$ practice were retained. Those relating to material science and technology development using C\&D waste were seen irrelevant to management practice and thus removed. The first round of screening resulted in 183 articles. In the second round screening, the titles, keywords, and abstracts of the 183 articles were carefully checked. For articles to be retained, the article had to report either the general factors influencing C\&D $\mathrm{WM}$, or the factors positively (i.e., drivers) or negatively (i.e., barriers) influencing C\&D WM. The articles not focused on the factors influencing C\&D WM were excluded. Finally, 106 articles were retained for further analysis.

\section{Stakeholder-Associated Factors}

Stakeholders are classified into external and internal stakeholders. External stakeholders include governments, the general public, and experts (e.g., academics, researchers), while internal stakeholders are direct participants of construction projects and waste recycling, including clients, designers, contractors (including subcontractors), and waste recycling companies [67]. This study discusses the influence of stakeholder-associated factors on C\&D WM. Table 1 shows a list of 35 factors influencing C\&D WM. Each factor is linked to at least one stakeholder, which initiates or is directly engaged in the factor.

Table 1. Stakeholder-associated factors influencing construction and demolition (C\&D) waste management (WM).

\begin{tabular}{|c|c|c|c|}
\hline Group & No. & Factor & Influential Stakeholder \\
\hline \multirow{5}{*}{ Regulatory environment } & 1 & Sufficient legislation and regulations & Governments \\
\hline & 2 & Enforcement of regulations & Governments \\
\hline & 3 & Financial incentives & Governments \\
\hline & 4 & Landfill levies & Governments \\
\hline & 5 & Fines and penalties & Governments \\
\hline \multirow{3}{*}{$\begin{array}{l}\text { Government and public } \\
\text { supervision }\end{array}$} & 6 & Government supervision & Governments \\
\hline & 7 & Public participation in supervision & Governments, the public \\
\hline & 8 & Availability of the C\&D waste statistics & Governments, experts \\
\hline \multirow[t]{2}{*}{ Advances in technologies } & 9 & $\begin{array}{l}\text { Application of information and communication } \\
\text { technologies }\end{array}$ & $\begin{array}{l}\text { Experts, governments, contractors, } \\
\text { recycling companies }\end{array}$ \\
\hline & 10 & Maturity of the technologies to treat waste & $\begin{array}{l}\text { Experts, governments, contractors, } \\
\text { recycling companies }\end{array}$ \\
\hline \multirow{5}{*}{ Recycling market } & 11 & Availability of local waste recycling facilities & Recycling companies \\
\hline & 12 & Supplies of recyclable waste to recycling facilities & Contractors \\
\hline & 13 & $\begin{array}{l}\text { Specifications, technical or quality standards for } \\
\text { recycled products }\end{array}$ & Governments \\
\hline & 14 & Demand for recycled products & Contractors, the public, designers \\
\hline & 15 & Cost of recycling products & Governments, recycling companies \\
\hline
\end{tabular}


Table 1. Cont.

\begin{tabular}{|c|c|c|c|}
\hline Group & No. & Factor & Influential Stakeholder \\
\hline \multirow{9}{*}{$\begin{array}{l}\text { Knowledge, awareness, } \\
\text { attitude, and behaviour of } \\
\text { stakeholders }\end{array}$} & 16 & Knowledge and skills of staff & Contractors, clients, designers \\
\hline & 17 & Awareness and attitude of clients & Clients \\
\hline & 18 & Awareness, attitude and behaviour of designers & Designers \\
\hline & 19 & Awareness, attitude and behaviour of contractors & Contractors \\
\hline & 20 & Awareness and attitude of the public & The public \\
\hline & 21 & Training and education & $\begin{array}{l}\text { Experts, governments, contractors, } \\
\text { recycling companies }\end{array}$ \\
\hline & 22 & Top management support & Clients, contractors, designers \\
\hline & 23 & Organizational WM policies & Clients, contractors, designers \\
\hline & 24 & Supportive organizational culture & Clients, contractors, designers \\
\hline \multirow{11}{*}{ Project-specific factors } & 25 & $\begin{array}{l}\text { Communication, collaboration and coordination } \\
\text { among project participants }\end{array}$ & Clients, contractors, designers \\
\hline & 26 & Selecting contractors with C\&D WM capability & Clients \\
\hline & 27 & Effective contract management & Clients, contractors, designers \\
\hline & 28 & Formal waste management plans & Contractors \\
\hline & 29 & Site conditions for on-site waste treatment & Contractors \\
\hline & 30 & Effective site planning & Contractors \\
\hline & 31 & Effective material management & Contractors \\
\hline & 32 & Regular site inspection & Contractors \\
\hline & 33 & Incentives for workers & Contractors \\
\hline & 34 & Rework minimization & Contractors, designers \\
\hline & 35 & $\begin{array}{l}\text { Adoption of low-waste methods in design and } \\
\text { construction }\end{array}$ & Contractors, designers, experts \\
\hline
\end{tabular}

\subsection{Regulatory Environment}

Regulatory environment consists of several factors directly associated with governments or legislative bodies, which play a pivotal role in promoting and supervising C\&D WM. Clients, designers, contractors, and recycling companies are directly influenced by the regulatory environment in terms of C\&D WM.

\subsubsection{Legislation and Enforcement}

Sufficient legislation and regulations have been widely recognized as a critical factor contributing to effective C\&D WM practice in many countries or regions $[25,28,68]$. Governments usually promote C\&D WM through legislation and by enforcing laws, regulations, and policies for the construction industry [69], which provide an overarching framework with legal obligations as well as how these obligations are monitored and enforced. There have been a number of regional empirical studies covering the role of legislation and regulations in $C \& D W M$ practice.

In China, the Environmental Protection Law was enacted in 1989, in which C\&D WM was seen as a way to protect the environment. In the 2000s, various central government departments issued regulations regarding to C\&D WM [70]. Provincial and municipal governments can promulgate local regulations and policies that are suitable for their specific situations, under the overarching national laws and regulations promulgated by the central government. In Australia, reinforcing legislation is seen as a way to enhance C\&D WM [28]. In Canada, C\&D WM is regulated by provincial and municipal governments, and the majority of municipalities have enacted by-laws to outlaw the landfilling of specific C\&D waste [71]. In Japan, the government enforced several laws and regulations in 
2002, including the Construction Reuse Law and the Construction Engineering Materials Recycling Law. These laws help to achieve C\&D waste recycling through incentives [72], making it mandatory to recycle certain materials from demolition waste [73]. In the USA, the National Environmental Policy Act and Federal Resource Recovery Act were enacted in 1969 and 1970, respectively. Then, the Resource Conservation and Recovery Act was enacted in 1976, covering non-hazardous waste from C\&D debris. The Comprehensive Environmental Response Compensation and Liability Act was enacted in 1980, stating that contractors have obligations to manage their $C \& D$ waste $[70,74]$. In the EU, member countries can decide whether or not to legislate for C\&D WM [75]. However, a national regulation for C\&D WM is not necessarily a prerequisite for effective C\&D WM. For example, Poland has no national regulations for C\&D WM but obtains a high C\&D waste recovery rate above $90 \%$ [75].

Effectiveness of the regulations regarding C\&D WM is assured when these regulations are effectively enforced, and practitioners comply with them [76]. However, the extent to which the regulations are detailed, clear, and operable, significantly impacts the enforcement of the regulations. In China, Lu and Yuan [25] indicated that national laws and regulations are too general and some clauses are too vague for practitioners to follow. Yuan [26] investigated the regulatory environment for C\&D waste Shenzhen, China. Although the Shenzhen government had enacted seven regulations since 1993, the regulatory system was still immature, and the clauses of the local regulations were not detailed enough for practitioners to follow [26]. Additionally, Yeheyis et al. [71] reviewed the regulations regarding C\&D WM in Canada and found that there was lack of enforcement mechanisms that integrated the $3 \mathrm{R}$ principle into the life cycle of construction projects. In India, the enforcement of the Environmental Protection Agency regulations was weak, and thus contractors never recognized C\&D WM as their priority and tended to illegally dump waste [77].

\subsubsection{Incentive, Penalty, and Fee}

The construction industry is sensitive to cost, and thus WM should not become a cost burden for relevant stakeholders [32]. Financial incentives play a critical role in driving the adoption of C\&D WM practice and facilitating the development of the waste recycling market [28,78]. Financial incentives are usually seen as a policy tool [79] and can be in the forms of government subsidies, funds, and rewards for organizations, especially contractors and recycling companies, to offset their expenses relating to C\&D WM. Some of the government financial incentive or subsidies come from the revenues of landfill levies [80].

Imposing a landfill levy, which is also called a waste disposal charge, disposal tax, or landfill tax in various regions, aims to increase the cost of C\&D waste disposal in landfill and encourage reusing and recycling $C \& D$ waste materials $[28,69,81]$. Several empirical studies have discussed the role of a landfill levy in various countries or regions. In the $\mathrm{EU}$, although the landfill tax was perceived to drive waste recovery and recycling [82], it was not found correlated with the recovery rate of C\&D waste [75]. A case study in Germany revealed that the C\&D disposal tax was cost-effective to lower the direct disposal rate and enhance total recycling but had limited influence on the recycling of a high quality [83]. In Australia, landfill levies have been imposed by all states and territories except Northern Territory and Tasmania, and a part of these levies is used to improve enforcement and compliance and fund recycling practices [80]. However, some empirical studies questioned the effectiveness of landfill levy imposition. Yu et al. [84] revealed that the waste disposal charge in Hong Kong had been effective in reducing waste landfill in the first three years since its imposition, but the effectiveness could not be sustained because the charge scheme failed to motivate subcontractors to change construction methods for less waste. This was consistent with the findings of Poon et al. [85]. Illegal dumping has also been widely reported as a result of landfill levies in the countries or regions where government supervision on waste disposal behaviours is not strict enough [86,87]. 
Thus, previous studies have modelled the quantities of illegal dumping and attempted to determine an appropriate landfill levy through the system dynamics technique [86,88].

Fines and penalties have been widely used in legislation and regulations to influence attitudes and behaviours of internal stakeholders in C\&D WM [14,79]. Calvo et al. [82] indicated that Spain's goal of recycling C\&D waste could be achieved in 10 years using tax penalties, which was faster than 12 years using financial incentives. Ajayi and Oyedele [79] suggested that increasing penalties for poor waste performance should be incorporated in the UK's C\&D WM policies. Penalties tend to reduce illegal dumping of C\&D waste, while excessive penalties have limitations. However, the impact of penalties on the C\&D waste generation could not be sustained in the long term [89]. Thus, several previous studies have investigated the reasonable ranges of fines and penalties [36,90]. Mahpour and Mortaheb [91] found that financial incentives were more efficient in promoting professional ethics and motivating stakeholders to minimize C\&D waste than punishment in Iran.

\subsection{Government and Public Supervision}

Government supervision is critical to assure the enforcement of relevant regulations and reduce illegal waste dumping [82,92,93]. In an empirical study in Mainland China, Wu et al. [94] argued that governments should impose strict supervision on WM behaviour, as government supervision was the second most important factor contributing to contractors' C\&D WM behaviour. Government supervision also has an effect on waste recycling companies. Long et al. [95] revealed that a higher-level of government supervision intensity would better motivate waste recycling companies. However, governments do not have to consistently intervene with companies, and their roles vary at different stages of the development of the C\&D waste recycling market. Su [96] adopted game theory to analyse the evolutionary decision-making process among governments, waste recycling companies, and contractors and argued that governments will gradually reduce their interventions and supervision as the $C \& D$ waste recycling industry becomes mature.

Although government supervision contributes to enforcement of the regulations relating to C\&D WM, the probability or intensity of such supervision tends to be insufficient due to limited resources available. Selective government supervision tends to result in opportunistic behaviour and illegal dumping of C\&D waste [36]. Therefore, the public could be encouraged to supervise and report illegal dumping to alleviate the pressure of governments. Chen et al. [90] indicated that involving the public in supervision can supplement government supervision and effectively reduced illegal dumping and suggested that governments should set supervision hotlines and information platforms to encourage public participation in supervision and reporting, while Du et al. [36] reported that the marginal benefits of public participation would decrease if financial incentives were high enough.

Waste statistics are required to show the imperativeness of C\&D WM, encourage public environmental awareness, and facilitate the development of WM policies and specifications $[26,97,98]$. These may include the amount of waste generated, reuse and recycling rate, etc. In developed countries or regions, such as the USA, Australia, and Hong Kong, governments publish periodic statistics of solid waste, covering C\&D waste statistics. By contrast, in developing countries, the governments may not prioritize releasing sufficient and accurate $C \& D$ waste statistics [14]. Experts or researchers may be engaged to estimate and predict the waste generation statistics [99,100]. Yuan [26] found that the quantities of the C\&D waste generation in Shenzhen, China were estimated by researchers based on the surveys with limited sample projects because the government did not attempt to collect real-time fundamental $C \& D$ waste data.

\subsection{Advances in Relevant Technologies}

In the past two decades, ICTs and recycling technologies have rapidly developed, which is attributed to the research and development efforts of experts and researchers, contractors, and recycling companies, with the support from governments. 
In previous studies, several ICTs were applied in C\&D WM and helped to improve its efficiency and solve some key issues. For instance, barcode technology was used to facilitate effective on-site material management and reduce construction waste [101]; GPS could be installed on transportation vehicles to monitor C\&D waste movement [102]; BIM was applied to estimate the life-cycle carbon emission of C\&D waste [103] and plan for concrete and drywall waste recycling and reuse [104]; GIS was used to quantify C\&D waste from generation to disposal [105], plan for waste sorting areas [106], and detect the areas with possible illegal dumping [107]; big data analytics was applied to minimize waste in design [108], identify illegal dumping [109], and analyse the factors contributing to C\&D waste generation [110]; RFID was applied with rule-based reasoning technology to enable waste recycling companies to track C\&D waste transportation [111]; computer vision technology was used in robot for waste sorting [112]; and image recognition technology was adopted with Google Earth to provide fast and accurate prediction of demolition waste generated from urban renewal [113].

Promoting C\&D WM also requires the mature and reliable technologies that can perform waste sorting, waste treatment, and waste recycling. Several studies have focused on the ability and efficiency of technologies, such as waste sorting technology [6], on-site recycling equipment [27], and the technologies that produce recycled concrete aggregates [114,115] and glass aggregates [116]. C\&D waste recycling technologies, such as concrete and cement separation, concrete and aggregate recycling, and carbonization of waste, have been mature and widely applied in Japan, Germany, and Singapore [15], which has led to high recycling rates. However, the technologies to produce recycled materials were not mature in developing countries. Huang et al. [15] indicated that only medium- and low-strength recycled concrete could be produced in China and found that immature recycling technologies were a critical challenge for adopting the circular economy in C\&D WM.

\subsection{CED Waste Recycling Market}

Building C\&D waste recycling facilities or factories has been recognized as an effective way to improve waste recycling rates and reduce landfilling [26] and is an important node of the supply chain for $C \& D$ waste recycling. The economic viability of waste recycling facilities should be taken into consideration. Gangolells et al. [117] revealed that the treatment capacity of such facilities in a region should be consistent with the construction industry growth and not exceed the real demand. Additionally, location of recycling facilities also impacts WM performance. Lingard et al. [35] found that availability of local waste recycling facilities was the top concern of contractors. If there are not recycling facilities nearby, transportation costs may be higher than landfill levies, which is not economically viable for contractors [118]. Thus, contractors may directly send waste to landfill sites. Several previous studies have investigated how to determine the location of recycling facilities $[119,120]$. Additionally, some studies investigated possibilities of on-site waste recycling, which aimed to minimize transporting waste to off-site recycling facilities [27].

A mature $C \& D$ waste recycling market enables the recycling of $C \& D$ waste and brings about a higher recycling rate. Governments play a critical role in promoting the waste recycling market [121] through financial incentives and legislation. Supplies of waste to recycling companies, prices and quality of recycled products and demands are also important to this market. If contractors have on-site recycling facilities or off-site recycling facilities are far from construction sites, contractors would not send their waste to off-site recycling facilities. Yuan [26] found that it was difficult for waste recycling companies to obtain recyclable waste from contractors in Mainland China.

In addition, that lack of specifications, technical, or quality standards for recycled products tend to result in concerns regarding the quality of these products and make them unattractive [82,122]. This also further leads to resistance to using recycled products and decreasing demands $[33,123]$. In addition, designers were found to be reluctant to specify recycled products in their designs [124] due to inadequate information about the 
market availability and quality, cost pressure, and negative perceptions of clients [125]. Tam et al. [126] found that one of the major obstacles to promoting recycled products was the opposition of local councils to using recycled products in new construction in Queensland, Australia.

Moreover, recycled products tend to go through more treatment processes, which increases cost and reduces price competitiveness. Huang et al. [15] indicated recycle products had no price advantages over those made from original materials in China because of the high cost associated with recycling treatment. Thus, waste recycling companies require government subsidies to survive, and the recycling market needs financial incentives to develop further [37]. Although the government subsidy is a useful policy tool, the government should assure it is practicable and feasible. Liu et al. [72] indicated that although subsidies were available according to the regional regulations of China, the strict conditions made it difficult for companies to apply for these subsidies.

\subsection{Knowledge, Awareness, Attitude, and Behaviour of Stakeholders}

Human-related factors, such as knowledge and skills, awareness, attitude, and behaviour of clients, designers, and contractors, have been recognized as influential to C\&D WM.

\subsubsection{Knowledge and Skills}

Knowledge and skills tend to impact behaviour of staff relating to WM [78,127]. Training and education may increase knowledge and skills of stakeholders. Previous studies have investigated the skills and knowledges of stakeholders and their influence on behaviour. For instance, Liu et al. [128] revealed that construction workers in the USA had strong environmental awareness and better relevant knowledge and skills regarding waste minimization than Chinese construction workers because relevant knowledge relating to recycling, green materials, and emission reduction was included in high school or college education; Udawatta et al. [32] found that inadequate experience and knowledge of WM hindered C\&D WM in Australia; and Sezer and Bosch-Sijtsema [129] indicated that clients had limited knowledge relating to WM in Sweden, resulting in vague demands from clients regarding WM and lack of relevant requirements in contractual documents.

\subsubsection{Awareness, Attitude, and Behaviour}

Awareness of the environmental impacts of C\&D waste, attitude towards C\&D WM, and the subsequent behaviour of C\&D WM have attracted great attention of researchers. The theory of planned behaviour and the extended theory of planned behaviour, institutional theory, and the norm activation model could be used as theoretical foundations to help explain pro-environmental behaviour relating to C\&D WM [130,131]. Awareness, attitude, and behaviour of different stakeholders should be taken into consideration to adopt C\&D WM [132].

Awareness and attitude of clients or developers significantly influence designers, contractors, and subcontractors in terms of C\&D WM [14,33]. Clients are usually profitdriven and sensitive to cost [67]. Although contractors are directly responsible for C\&D WM during construction, clients finally bear the cost associated with C\&D WM [30]. Therefore, clients tend to be passive to C\&D WM without perceivable profitability [133]. Government clients are more favourable towards WM practice than private clients [32]. Regulatory requirements and communicating the benefits (e.g., less accidents, better social image, and improved productivity) can positively change clients' attitude towards C\&D WM [71], which further trigger clients' commitment.

Design significantly influence waste $[134,135]$, and designers play an important role in minimizing C\&D WM, as one third of waste results from improper design [136]. Previous studies indicated that designers may not be aware of the potential of materials for waste minimization $[26,137]$ and misunderstand that waste is generated from site operations and not the design phase [42]. Designers with limited knowledge of materials and construction 
methods may lead to design changes, rework, and waste [138]. Thus, it is necessary to focus on the design phase that provides a good opportunity to minimize waste at the source [29]. BIM is a powerful tool for designing out C\&D waste [139]. In addition, organizational culture within design companies and the external environment also positively contribute to designers' attitude towards waste minimization [140]. As such, designers can inform clients of the benefits of reusing materials, undertake environmental impact assessment, adopt WM plans at an early design stage, and consider the life cycle of materials or components, including their eventual reuse, recycling, recovery, or disposal $[25,67,141]$.

Contractors and subcontractors are directly involved in the generation and management of C\&D waste and need to follow a WM plan [14]. As the construction industry is competitive by nature, it is not surprising that contractors and subcontractors aim to maximize profits [133] and may view C\&D WM a cost burden. Construction workers on site may consider C\&D waste as inevitable by-products [142], and subcontractors may have poor awareness and WM practice [143]. Through training and education, contractors and subcontractors may obtain relevant knowledge and skills, become aware of the environmental impact of waste, and hold positive attitudes towards C\&D WM $[28,67]$, which further contribute to WM behaviour [144]. Using theory of planned behaviour, $\mathrm{Wu}$ et al. [94] indicated that such positive attitudes were shaped by perceived benefits, including improved environmental quality, sustainable development, the company's brand benefit, improved social image, and the perception that it was worth promoting effective C\&D WM, whilst Jain et al. [130] believed that such attitudes were shaped by both perceived costs and benefits and the perception that perceived benefits can outweigh perceived costs.

Awareness and attitude of the public was found to influence C\&D WM in several empirical studies. For instance, Udawatta et al. [28] indicated that advertising benefits of C\&D WM through social media could improve public awareness, which enhances C\&D WM; Yuan [26] suggested that regularly releasing the C\&D waste statistical data to the public would effectively motive the environmental awareness of the public; and Li et al. [145] found that environmental concern of the public was one of the critical factors that should be considered when making C\&D WM policies. The public still has concerns regarding the quality of recycled materials. Lu et al. [146] and Akhtar and Sarmah [147] indicated that C\&D waste recycled products were viewed as inferior to the original products, while Udawatta et al. [32] revealed that the public in Australia was interested in recycled materials if they had competitive prices and reliable quality.

\subsubsection{Training and Education}

Training and education enable contractors, designers, and clients to increase employees' knowledge, attitudes, and awareness relating to WM and have been recognized as effective ways to improve C\&D WM in several countries, such as the USA [148], China [25,149], Australia [28,127], Vietnam [150], Malaysia [144], and the United Arab Emirates [151].

C\&D WM can be embedded in the training courses provided by government departments, universities, and research institutions [25]. Contractors have been the main subject of training on C\&D WM. In contractors, vocational training on C\&D WM provides their workers with skills to sort and reduce waste on site and enhance their awareness of environmental benefits of 3R activities [152]. The training time should be long enough to ensure the workers have all the necessary skills $[25,153]$ and understand why they practice WM [32]. Additionally, for designers and architects, education and continued professional development programs are expected to foster their positive awareness and attitude towards C\&D WM [67]. Moreover, governments may initiate information campaigns or use social media to promote the benefits of C\&D WM, which can enhance the public awareness and participation in supervision [32]. 


\subsubsection{Organizational Context}

A positive organizational context contributes to C\&D WM practice in an organization. Top management support and commitment is necessary to implement effective C\&D WM within organizations, because the attitude of top management influences the development and implementation of internal WM policies, organizational culture, and resources allocation for WM. Lingard et al. [35] found that top management support was viewed as a critical driver for C\&D WM by workers, site management staff, and headquarter management staff of contractors. Teo and Loosemore [142] revealed that WM would not be prioritized unless managers prioritized it and provided resources for it. Ling and Lim [154] indicated that WM should be a top-down approach and depended on top management support to succeed. Top management support may be driven by compliance with government legislation relating to C\&D WM.

Cultural change is essential for promoting WM practice [155]. With top management support in place, a supportive organizational culture can be developed gradually, which indirectly influences individuals' attitudes towards WM within a design company or contractor $[28,140]$. In addition, a WM policy at the organizational level could be created to identify the targets and strategies of waste reduction and the accountability for waste reduction.

\subsection{Project-Specific Factors}

Project-specific factors are those directly related to project planning and design, tendering, construction, and demolition phases. The project operation phase is not covered in this study. Clients, designers, and contractors (including subcontractors) are the project participants that are associated with C\&D WM.

\subsubsection{Communication and Coordination among Project Participants}

Communication and coordination among project participants can enhance mutual trust and reduce conflicts, positively change attitudes, and play an important role for effective C\&D WM in different project phases $[14,156,157]$. In the design phase, designers and clients communicate and coordinate to reuse $C \& D$ waste; reduce design errors, changes, and reworks; and reduce waste $[26,67,158]$. In the tendering phase, clients' demand for waste minimization should be declared and communicated to potential contractors. In the construction phase, communication between contractors and subcontractors contributes to trade of on-site recycled products [27]. All the relevant WM policies should be clearly communicated among project participants [142].

\subsubsection{Selecting Contractors with C\&D WM Capability}

The contractors with effective C\&D WM plans and relevant experience are more likely to minimize waste on site and comply with relevant legislation. Private clients tend to select the lowest bidder to minimize costs, while government clients may adopt prequalification procedures to select contractors based on their previous C\&D WM performance [32]. Previous studies have suggested that contractors' C\&D WM plans, policies, and past performance should be incorporated into the tender selection criteria $[25,137,153]$. This practice also demonstrates that clients hold positive attitudes towards WM, enhances the competitiveness of the contractors with strong C\&D WM capability, and reveals that cost and time are not the only focuses of clients [117].

\subsubsection{Effective Contract Management}

Contractual clauses have great potential for waste reduction [159]. The disclaimer or exculpatory clauses in standard contractual documents and the clauses regarding quality, workmanship, and site inspection are likely to result in rework and construction waste and thus require amendments $[160,161]$. Previous studies have recommended several amendments to reduce waste during construction, including setting waste and recycling targets for contractors and subcontractors and clarifying their responsibilities for 
WM $[117,137,159]$, minimising design changes or identifying the required design changes before the work impacted is started [134,159,162], and fostering high-level collaboration and risk sharing [28].

\subsubsection{Formal WM Plans}

At the project level, formal C\&D WM plans typically cover waste sorting, waste streams, waste clearance schedule, waste collection and transportation, waste reuse, recycling and disposal, possible issues and solutions, and required resources [4,25]. WM plans are developed in accordance with government regulations and organizational WM policies. As a well-recognized driver for effective WM, a WM plan should be adopted at the design stage for waste minimization [28]. As the effectiveness of WM plans is influenced by its compatibility with the actual situation [30], WM plans need to be monitored, reviewed and updated throughout a project $[70,117]$.

\subsubsection{Site Conditions for On-Site Waste Treatment}

On-site waste sorting can significantly increase reuse and recycling rate and reduce pollution and waste transportation cost and disposal $[163,164]$, whilst on-site waste treatment and recycling on site can minimize the nuisance relating to transporting waste to off-site recycling factories [27]. However, adequate site space is required to allocated for placing equipment, waste collecting, sorting, treatment, and recycling [163]. Previous studies have indicated that limited site space hindered the implementation of on-site waste sorting [4,5] and on-site waste recycling [27] in Hong Kong, where construction sites are usually located in crowded neighbourhoods, and building retrofit projects, which involve existing buildings in operation with constrained site space [165]. Therefore, site managers should plan the site for on-site WM.

\subsubsection{Effective Site Management}

Effective management of all the on-site activities contributes to $C \& D$ waste reduction. Effective site planning, including planning the space for waste collection and sorting, is necessary to ensure the WM process and stockpiles do not interfere with other construction activities on site and enable on-site material to avoid contamination or being disposed of as mixed waste [71,137]. In addition, effective material management is also essential for C\&D WM. Previous studies have revealed optimal purchasing management, proper handling of materials, proper storage of materials, proper access to storage areas for deliveries, and the provision of central areas for cutting materials should be assured to effectively manage materials on site $[25,137,162,166,167]$. Additionally, regular site inspection should be undertaken, and performance of WM should be reviewed to identify additional requirements of waste reduction $[137,168]$. An on-site incentive system within contractors may be used to reward the staff producing a lower amount of waste [152]. Furthermore, on-site rework needs to be minimized, and any packed materials should be collected [169].

\subsubsection{Adoption of Low-Waste Methods in Design and Construction}

Adoption of low-waste methods in design and construction significantly contributes to waste reduction. Lean construction, which adopts lean principles in construction to create value and eliminate non-value-adding activities, focuses on eliminating waste from construction processes $[28,170]$.

In addition, off-site construction and precasting or prefabrication technologies, which produce building components in off-site factories, have been found to considerably reduce construction waste $[136,171,172]$, despite disadvantages relating to lower flexibility with manufacturing and transportation problems [173]. Using reusable temporary work, such as metal formwork, can also reduce waste [137].

Moreover, WM is one of the assessment criteria of some widely-used green building rating systems, such as Green Star in Australia, Building Research Establishment's Envi- 
ronmental Assessment Method (BREEAM) in the UK, Green Building Index in Malaysia, and Green Mark in Singapore [174,175]. Thus, achieving a green building rating is also a low-waste method.

Furthermore, Zhang et al. [176] and Poon et al. [177] identified several low-waste methods for construction and design, including design for thin floor slabs and internal walls, design for reducing foundation size, design for reusing excavated spoils as back-fill materials, design for recycled materials, sequential demolition technology, use of large panel formwork, design for hanging cradles, and modular building designs.

\section{Conclusions and Recommendations}

C\&D WM practice is influenced by a variety of factors, which could be associated with various stakeholders. These stakeholders usually have different interests and goals and influence C\&D WM through relevant factors. Thus, the stakeholders should clearly understand their roles and responsibilities in C\&D WM and make better informed decisions in the C\&D WM process. This study undertook a systematic literature review of the stakeholder-associated factors influencing C\&D WM. Through an initial search in the Scopus search engine and two rounds of screening, this study focused on 106 journal articles for analysis, each of which was checked carefully to identify stakeholder-associated factors. Finally, a total of 35 factors were identified and categorized into six groups: regulatory environment, government and public supervision, advances in technologies, recycling market, knowledge, awareness, attitude and behaviour of stakeholders, and project-specific factors. Each of these factors was linked to at least one stakeholder.

The regulatory environment creates compliance pressures for internal stakeholders, such as clients, designers, and contractors, to adopt C\&D WM. This also consists of rewardpenalty schemes, which economically drive C\&D WM. Any non-compliance behaviour, such as illegal waste dumping, should be monitored and punished to assure strict enforcement of regulations. Government supervision is required, but supervision intensity is usually not enough because of resource constraints. Government supervision could be supplemented by public participation in supervision. Public participation is usually motivated by the environmental awareness encouraged by disclosing C\&D waste statistics and information campaigns. C\&D waste statistics also contribute to government policy making but are usually unavailable in developing countries. In some cases, researchers or experts are invited to estimate or predict waste statistical data.

Implementing C\&D WM cannot be separated from the advanced ICTs (such as BIM, GIS, RFID, computer vision, etc.) and recycling technologies. The development of these technologies is attributed to the efforts of experts, contractors, and recycling companies, which are fully or partially supported by government research grants. Some of the technologies can be used for government supervision, design optimization, on-site waste sorting, and recycling.

C\&D waste recycling facilities should be built up to accept the recyclable waste from contractors. However, the transportation cost is highly related to the location of such facilities. In addition, such recycling facilities represent only one of the various stakeholders of the C\&D waste recycling market. They also need to assure the supply of recyclable C\&D waste from contractors and the demand for the recycled products. The quality of recycled products should be in accordance with relevant specifications or technical standards. However, if there are no such specifications or standards, concerns regarding quality will arise. In addition, the high cost of recycling waste through multiple complex treatment processes tends to incur higher prices, making the recycled products uncompetitive compared to those made from original materials. Thus, government subsidy can help recycling companies to survive before the $C \& D$ waste recycling market becomes mature.

The knowledge, skills, awareness, attitude, and behaviour of internal stakeholders, such as clients, designers, and contractors, are usually viewed as human-related factors. Education and training can help enhance these factors and enable stakeholders to have 
positive attitudes toward C\&D WM. It should be noted that awareness, attitude, and behaviour of clients can influence those of designers and contractors. In turn, designers can also influence clients and promote reusable and recyclable materials to clients, while contractors can demonstrate practical benefits of C\&D WM to clients, which strengthens clients' positive attitudes. In addition, within each stakeholder, the organizational context, covering top management commitment, organizational culture, and internal WM policies, can also influence staffs' attitudes and behaviours relating to C\&D WM.

With a project life cycle perspective, project planning and design, tendering, construction, and demolition phases and relevant stakeholders influence C\&D WM practice. Thus, communication and coordination among clients, designers, and contractors (including subcontractors) in various project phases are important for effective C\&D WM. Designers need to adopt low-waste methods in design. Clients need to incorporate the C\&D WM capability of contractors into prequalification and tendering criteria. Contractual documents may be amended to include specific WM targets and responsibilities for contractors and methods to minimize rework and waste. During construction, contractors need to follow their WM plans and adopt lean construction or prefabrication methods to minimize C\&D waste on site. Contractors also need to perform on-site waste recycling, transport waste to off-site recycling facilities, or send the non-recyclable waste to landfill sites. This process should be supervised by clients and governments.

There are some limitations of this study. First, this study does not adopt any quantitative analysis of the literatures but is based on qualitative analysis. This is different from a quantitative scientometric review. Second, this study reviewed the journal publications written in English only. There may be significant and relevant articles in other languages. Third, with the passage of time, the 35 factors identified in this study may not be exhaustive or comprehensive. Fourth, this review focuses on the articles in Scopus while excluding some grey literatures that may be helpful. Nonetheless, this study still provides practitioners with an understanding of the stakeholder-associated factors and sets a basis for future studies focused on the stakeholders in C\&D WM.

As the roles of stakeholders change throughout a project life cycle, the interactions among stakeholder-associated factors will change accordingly. Future studies should hold a dynamic view and investigate how the network of these interactions among factors evolve in different project phases. In addition, as the regulatory environment is an important driving force contributing to C\&D WM, future studies should collect longitudinal data to simulate how the stakeholders collaborate with each other at different stages after the enforcement of relevant regulations in a period. This will help clearly demonstrate the role of the regulatory environment in promoting C\&D WM. Moreover, project characteristics, such as project size or duration, and organizational characteristics, such as company size, could moderate C\&D WM practice. Future studies would examine the moderation effects of these characteristic variables on the factors influencing C\&D WM practice. Furthermore, the development of emerging technologies, such as the ICTs that enhance C\&D WM [47] and the biotechnologies that are capable of producing biofuels using biomass waste from construction sites [178-180], will involve more stakeholders. Future studies would update the list of stakeholders with new stakeholders and the factors associated with them.

Funding: This research received no external funding.

Conflicts of Interest: The authors declare no conflict of interest.

\section{References}

1. Yuan, H. A SWOT analysis of successful construction waste management. J. Clean. Prod. 2013, 39, 1-8. [CrossRef]

2. Jin, R.; Yuan, H.; Chen, Q. Science mapping approach to assisting the review of construction and demolition waste management research published between 2009 and 2018. Resour. Conserv. Recycl. 2019, 140, 175-188. [CrossRef]

3. Tchobanoglous, G.; Eliassen, R.; Theisen, H. Solid Wastes; Engineering Principles and Management Issues; Mcgraw-Hill: New York City, NY, USA, 1977.

4. Poon, C.S.; Yu, A.T.W.; Ng, L.H. On-site sorting of construction and demolition waste in Hong Kong. Resour. Conserv. Recycl. 2001, 32, 157-172. [CrossRef] 
5. Yuan, H.; Lu, W.; Jianli Hao, J. The evolution of construction waste sorting on-site. Renew. Sustain. Energy Rev. 2013, 20, 483-490. [CrossRef]

6. Hyvärinen, M.; Ronkanen, M.; Kärki, T. Sorting efficiency in mechanical sorting of construction and demolition waste. Waste Manag. Res. 2020, 38, 812-816. [CrossRef]

7. Modak, P.; Wilson, D.C.; Velis, C. Waste Management: Global Status. In Global Waste Management Outlook; Wilson, D.C., Ed.; United Nations Environment Programme: Nairobi, Kenya, 2015.

8. Eurostat. Waste Statistics. Available online: https://ec.europa.eu/eurostat/statistics-explained/index.php/Waste_statistics\# Waste_generation_excluding_major_mineral_waste (accessed on 24 November 2020).

9. $\quad$ Pickin, J.; Randell, P.; Trinh, J.; Grant, B. National Waste Report 2018; Department of the Environment and Energy Australia: Canberra, Australia, 2018.

10. Rosado, L.P.; Vitale, P.; Penteado, C.S.; Arena, U. Life cycle assessment of construction and demolition waste management in a large area of São Paulo State, Brazil. Waste Manag. 2019, 85, 477-489. [CrossRef]

11. Forward. Report of Market Research and Investment Forecast Analysis on China Construction and Demolition Waste Disposal Industry (2020-2025); Forward Business Information Co. Ltd.: Shenzhen, China, 2020.

12. US Environmental Protection Agency. Facts and Figures about Materials, Waste and Recycling. Available online: https://www. epa.gov/facts-and-figures-about-materials-waste-and-recycling/construction-and-demolition-debris-material (accessed on 9 December 2020).

13. Bao, Z.; Lu, W. Developing efficient circularity for construction and demolition waste management in fast emerging economies: Lessons learned from Shenzhen, China. Sci. Total Environ. 2020, 724, 138264. [CrossRef]

14. Kabirifar, K.; Mojtahedi, M.; Wang, C.; Tam, V.W.Y. Construction and demolition waste management contributing factors coupled with reduce, reuse, and recycle strategies for effective waste management: A review. J. Clean. Prod. 2020, 263, 121265. [CrossRef]

15. Huang, B.; Wang, X.; Kua, H.; Geng, Y.; Bleischwitz, R.; Ren, J. Construction and demolition waste management in China through the 3R principle. Resour. Conserv. Recycl. 2018, 129, 36-44. [CrossRef]

16. El-Haggar, S.M. Sustainable Industrial Design and Waste Management: Cradle-to-Cradle for Sustainable Development; Elsevier Academic Press: Maryland Heights, MO, USA, 2007.

17. Hwang, B.G.; Yeo, Z.B. Perception on benefits of construction waste management in the Singapore construction industry. Eng. Constr. Archit. Manag. 2011, 18, 394-406. [CrossRef]

18. Menegaki, M.; Damigos, D. A review on current situation and challenges of construction and demolition waste management. Curr. Opin. Green Sustain. Chem. 2018, 13, 8-15. [CrossRef]

19. Jin, R.; Li, B.; Zhou, T.; Wanatowski, D.; Piroozfar, P. An empirical study of perceptions towards construction and demolition waste recycling and reuse in China. Resour. Conserv. Recycl. 2017, 126, 86-98. [CrossRef]

20. Zhao, Y.; Huang, S. Pollution Control and Resource Recovery: Industrial Construction and Demolition Wastes; Butterworth-Heinemann: Oxford, UK, 2016.

21. Ding, Z.; Wang, Y.; Zou, P.X.W. An agent based environmental impact assessment of building demolition waste management: Conventional versus green management. J. Clean. Prod. 2016, 133, 1136-1153. [CrossRef]

22. Zhang, Y.; Tan, W. Demolition waste recycling in China: New evidence from a demolition project for highway development. Waste Manag. Res. 2020, 38, 696-702. [CrossRef]

23. Saju, M.T. India Recycles Only 1\% of Construction and Demolition Waste. Available online: https://timesofindia.indiatimes. $\mathrm{com} /$ business/india-business/india-recycles-only-1-of-construction-and-demolition-waste-study-finds/articleshow / 777470 60.cms (accessed on 24 November 2020).

24. Yuan, H.; Shen, L. Trend of the research on construction and demolition waste management. Waste Manag. 2011, 31, 670-679. [CrossRef]

25. Lu, W.; Yuan, H. Exploring critical success factors for waste management in construction projects of China. Resour. Conserv. Recycl. 2010, 55, 201-208. [CrossRef]

26. Yuan, H. Barriers and countermeasures for managing construction and demolition waste: A case of Shenzhen in China. J. Clean Prod. 2017, 157, 84-93. [CrossRef]

27. Bao, Z.; Lee, W.M.W.; Lu, W. Implementing on-site construction waste recycling in Hong Kong: Barriers and facilitators. Sci. Total Environ. 2020, 747, 141091. [CrossRef]

28. Udawatta, N.; Zuo, J.; Chiveralls, K.; Zillante, G. Improving waste management in construction projects: An Australian study. Resour. Conserv. Recycl. 2015, 101, 73-83. [CrossRef]

29. Ajayi, S.O.; Oyedele, L.O. Critical design factors for minimising waste in construction projects: A structural equation modelling approach. Resour. Conserv. Recycl. 2018, 137, 302-313. [CrossRef]

30. Manowong, E. Investigating factors influencing construction waste management efforts in developing countries: An experience from Thailand. Waste Manag. Res. 2012, 30, 56-71. [CrossRef]

31. Poon, C.S.; Yu, A.T.W.; Wong, S.W.; Cheung, E. Management of construction waste in public housing projects in Hong Kong. Constr. Manag. Econ. 2004, 22, 675-689. [CrossRef]

32. Udawatta, N.; Zuo, J.; Chiveralls, K.; Zillante, G. Attitudinal and behavioural approaches to improving waste management on construction projects in Australia: Benefits and limitations. Int. J. Constr. Manag. 2015, 15, 137-147. [CrossRef] 
33. Udawatta, N.; Zuo, J.; Chiveralls, K.; Yuan, H.; Zillante, G.; Elmualim, A. Major factors impeding the implementation of waste management in Australian construction projects. J. Green Build. 2018, 13, 101-121. [CrossRef]

34. Kim, S.Y.; Nguyen, M.V.; Luu, V.T. A performance evaluation framework for construction and demolition waste management: Stakeholder perspectives. Eng. Constr. Archit. Manag. 2020, 27, 3189-3213. [CrossRef]

35. Lingard, H.; Graham, P.; Smithers, G. Employee perceptions of the solid waste management system operating in a large Australian contracting organization: Implications for company policy implementation. Constr. Manag. Econ. 2000, 18, 383-393. [CrossRef]

36. Du, L.; Feng, Y.; Lu, W.; Kong, L.; Yang, Z. Evolutionary game analysis of stakeholders' decision-making behaviours in construction and demolition waste management. Environ. Impact Assess. Rev. 2020, 84. [CrossRef]

37. Su, Y.; Si, H.; Chen, J.; Wu, G. Promoting the sustainable development of the recycling market of construction and demolition waste: A stakeholder game perspective. J. Clean. Prod. 2020, 277, 122281. [CrossRef]

38. Li, J.; Tam, V.W.; Zuo, J.; Zhu, J. Designers' attitude and behaviour towards construction waste minimization by design: A study in Shenzhen, China. Resour. Conserv. Recycl. 2015, 105, 29-35. [CrossRef]

39. Osmani, M.; Glass, J.; Price, A. Architect and Contractor Attitudes to Waste Minimization. In Proceedings of the Institution of the Civil Engineers-Waste and Resource Management, London, UK, 1 November 2017; Volume 170, pp. 65-72.

40. Begum, R.A.; Siwar, C.; Pereira, J.J.; Jaafar, A.H. A benefit-cost analysis on the economic feasibility of construction waste minimisation: The case of Malaysia. Resour. Conserv. Recycl. 2006, 48, 86-98. [CrossRef]

41. Shen, H.; Peng, Y.; Guo, C. Analysis of the evolution game of construction and demolition waste recycling behavior based on prospect theory under environmental regulation. Int. J. Environ. Res. Public Health 2018, 15, 1518. [CrossRef] [PubMed]

42. Osmani, M.; Glass, J.; Price, A.D.F. Architects' perspectives on construction waste reduction by design. Waste Manag. 2008, 28, 1147-1158. [CrossRef] [PubMed]

43. Baumeister, R.F.; Leary, M.R. Writing narrative literature reviews. Rev. Gen. Psychol. 1997, 1, 311-320. [CrossRef]

44. Snyder, H. Literature review as a research methodology: An overview and guidelines. J. Bus. Res. 2019, 104, 333-339. [CrossRef]

45. Webster, J.; Watson, R.T. Analyzing the past to prepare for the future: Writing a literature review. MIS Q. 2002, 26, xiii-xxiii.

46. Zhao, X.; Ke, Y.; Zuo, J.; Xiong, W.; Wu, P. Evaluation of sustainable transport research in 2000-2019. J. Clean. Prod. 2020, 256, 120404. [CrossRef]

47. Li, C.Z.; Zhao, Y.; Xiao, B.; Yu, B.; Tam, V.W.Y.; Chen, Z.; Ya, Y. Research trend of the application of information technologies in construction and demolition waste management. J. Clean. Prod. 2020, 263. [CrossRef]

48. Faruqi, M.H.Z.; Siddiqui, F.Z. A mini review of construction and demolition waste management in India. Waste Manag. Res. 2020, 38, 708-716. [CrossRef]

49. Daoud, A.O.; Othman, A.A.E.; Robinson, H.; Bayyati, A. An investigation into solid waste problem in the Egyptian construction industry: A mini-review. Waste Manag. Res. 2020, 38, 371-382. [CrossRef]

50. Bergsdal, H.; Bohne, R.A.; Brattebø, H. Projection of construction and demolition waste in Norway. J. Ind. Ecol. 2007, 11, 27-39. [CrossRef]

51. Esa, M.R.; Halog, A.; Rigamonti, L. Developing strategies for managing construction and demolition wastes in Malaysia based on the concept of circular economy. J. Mater. Cycles Waste Manag. 2017, 19, 1144-1154. [CrossRef]

52. Boltakova, N.V.; Faseeva, G.R.; Kabirov, R.R.; Nafikov, R.M.; Zakharov, Y.A. Utilization of inorganic industrial wastes in producing construction ceramics. Review of Russian experience for the years 2000-2015. Waste Manag. 2017, 60, 230-246. [CrossRef]

53. Goldstein, J. Just how "wicked" is Beijing's waste problem? A response to "The rise and fall of a "waste city" in the construction of an "urban circular economic system": The changing landscape of waste in Beijing" by Xin Tong and Dongyan Tao. Resour. Conserv. Recycl. 2017, 117, 177-182. [CrossRef]

54. Behera, M.; Bhattacharyya, S.K.; Minocha, A.K.; Deoliya, R.; Maiti, S. Recycled aggregate from C\&D waste \& its use in concrete-A breakthrough towards sustainability in construction sector: A review. Constr. Build. Mater. 2014, 68, 501-516. [CrossRef]

55. Tamanna, K.; Raman, S.N.; Jamil, M.; Hamid, R. Utilization of wood waste ash in construction technology: A review. Constr. Build. Mater. 2020, 237. [CrossRef]

56. Sudharsan, N.; Palanisamy, T.; Yaragal, S.C. Environmental sustainability of waste glass as a valuable construction material-A critical review. Ecol. Environ. Conserv. 2018, 24, S331-S338.

57. Tam, V.W.Y.; Tam, C.M. A review on the viable technology for construction waste recycling. Resour. Conserv. Recycl. 2006, 47, 209-221. [CrossRef]

58. Sormunen, P.; Kärki, T. Recycled construction and demolition waste as a possible source of materials for composite manufacturing. J. Build. Eng. 2019, 24. [CrossRef]

59. Wu, H.; Zuo, J.; Zillante, G.; Wang, J.; Yuan, H. Construction and demolition waste research: A bibliometric analysis. Archit. Sci. Rev. 2019, 62, 354-365. [CrossRef]

60. Borrego, M.; Foster, M.J.; Froyd, J.E. Systematic literature reviews in engineering education and other developing interdisciplinary fields. J. Eng. Educ. 2014, 103, 45-76. [CrossRef]

61. Falagas, M.E.; Pitsouni, E.I.; Malietzis, G.A.; Pappas, G. Comparison of PubMed, Scopus, web of science, and Google scholar: Strengths and weaknesses. FASEB J. 2008, 22, 338-342. [CrossRef] [PubMed]

62. Jin, R.; Zou, P.X.W.; Piroozfar, P.; Wood, H.; Yang, Y.; Yan, L.; Han, Y. A science mapping approach based review of construction safety research. Saf. Sci. 2019, 113, 285-297. [CrossRef] 
63. Darko, A.; Chan, A.P.; Huo, X.; Owusu-Manu, D.-G. A scientometric analysis and visualization of global green building research. Build. Environ. 2019, 149, 501-511. [CrossRef]

64. Zhao, X.; Zuo, J.; Wu, G.; Huang, C. A bibliometric review of green building research 2000-2016. Archit. Sci. Rev. 2019, 62, 74-88. [CrossRef]

65. Eva, N.; Newman, A.; Jiang, Z.; Brouwer, M. Career optimism: A systematic review and agenda for future research. J. Vocat. Behav. 2020, 116, 103287. [CrossRef]

66. Luo, L.; He, Q.; Jaselskis, E.J.; Xie, J. Construction project complexity: Research trends and implications. J. Constr. Eng. Manag. 2017, 143, 04017019. [CrossRef]

67. Park, J.; Tucker, R. Overcoming barriers to the reuse of construction waste material in Australia: A review of the literature. Int. J. Constr. Manag. 2017, 17, 228-237. [CrossRef]

68. Liu, H.; Long, H.; Li, X. Identification of critical factors in construction and demolition waste recycling by the grey-DEMATEL approach: A Chinese perspective. Environ. Sci. Pollut. Res. 2020, 27, 8507-8525. [CrossRef]

69. Jaillon, L.; Poon, C.-S. Sustainable construction aspects of using prefabrication in dense urban environment: A Hong Kong case study. Constr. Manag. Econom. 2008, 26, 953-966. [CrossRef]

70. Aslam, M.S.; Huang, B.; Cui, L. Review of construction and demolition waste management in China and USA. J. Environ. Manag. 2020, 264. [CrossRef]

71. Yeheyis, M.; Hewage, K.; Alam, M.S.; Eskicioglu, C.; Sadiq, R. An overview of construction and demolition waste management in Canada: A lifecycle analysis approach to sustainability. Clean Technol. Environ. Policy 2013, 15, 81-91. [CrossRef]

72. Liu, J.; Yi, Y.; Wang, X. Exploring factors influencing construction waste reduction: A structural equation modeling approach. J. Clean. Prod. 2020, 276, 123185. [CrossRef]

73. Tam, V.W.Y. Comparing the implementation of concrete recycling in the Australian and Japanese construction industries. J. Clean. Prod. 2009, 17, 688-702. [CrossRef]

74. Clark, C.; Jambeck, J.; Townsend, T. A review of construction and demolition debris regulations in the United States. Crit. Rev. Environ. Sci. Technol. 2006, 36, 141-186. [CrossRef]

75. Villoria Sáez, P.; Osmani, M. A diagnosis of construction and demolition waste generation and recovery practice in the European Union. J. Clean. Prod. 2019, 241. [CrossRef]

76. Seror, N.; Portnov, B.A. Estimating the effectiveness of different environmental law enforcement policies on illegal C\&D waste dumping in Israel. Waste Manag. 2020, 102, 241-248. [CrossRef]

77. Kolaventi, S.S.; Tezeswi, T.P.; Siva Kumar, M.V.N. An assessment of construction waste management in India: A statistical approach. Waste Manag. Res. 2019. [CrossRef]

78. Bakshan, A.; Srour, I.; Chehab, G.; El-Fadel, M.; Karaziwan, J. Behavioral determinants towards enhancing construction waste management: A Bayesian Network analysis. Resour. Conserv. Recycl. 2017, 117, 274-284. [CrossRef]

79. Ajayi, S.O.; Oyedele, L.O. Policy imperatives for diverting construction waste from landfill: Experts' recommendations for UK policy expansion. J. Clean. Prod. 2017, 147, 57-65. [CrossRef]

80. Shooshtarian, S.; Maqsood, T.; Khalfan, M.; Yang, R.J.; Wong, P. Landfill levy imposition on construction and demolition waste: Australian stakeholders' perceptions. Sustainability 2020, 12, 4496. [CrossRef]

81. Del Río Merino, M.; Gracia, P.I.; Azevedo, I.S.W. Sustainable construction: Construction and demolition waste reconsidered Waste Manag. Res. 2010, 28, 118-129. [CrossRef]

82. Calvo, N.; Varela-Candamio, L.; Novo-Corti, I. A dynamic model for construction and demolition (C\&D) waste management in Spain: Driving policies based on economic incentives and tax penalties. Sustainability 2014, 6, 416-435. [CrossRef]

83. Hiete, M.; Stengel, J.; Ludwig, J.; Schultmann, F. Matching construction and demolition waste supply to recycling demand: A regional management chain model. Build. Res. Inf. 2011, 39, 333-351. [CrossRef]

84. Yu, A.T.W.; Poon, C.S.; Wong, A.; Yip, R.; Jaillon, L. Impact of Construction Waste Disposal Charging Scheme on work practices at construction sites in Hong Kong. Waste Manag. 2013, 33, 138-146. [CrossRef]

85. Poon, C.S.; Yu, A.T.W.; Wong, A.; Yip, R. Quantifying the impact of construction waste charging scheme on construction waste management in Hong Kong. J. Constr. Eng. Manag. 2013, 139, 466-479. [CrossRef]

86. Yuan, H.; Wang, J. A system dynamics model for determining the waste disposal charging fee in construction. Eur. J. Oper. Res. 2014, 237, 988-996. [CrossRef]

87. Rameezdeen, R.; Chileshe, N.; Hosseini, M.R.; Lehmann, S. A qualitative examination of major barriers in implementation of reverse logistics within the South Australian construction sector. Int. J. Constr. Manag. 2016, 16, 185-196. [CrossRef]

88. Au, L.S.; Ahn, S.; Kim, T.W. System dynamic analysis of impacts of government charges on disposal of construction and demolition waste: A Hong Kong case study. Sustainability 2018, 10, 1077. [CrossRef]

89. Liu, J.; Teng, Y.; Wang, D.; Gong, E. System dynamic analysis of construction waste recycling industry chain in China. Environ. Sci. Pollut. Res. 2020, 27, 37260-37277. [CrossRef]

90. Chen, J.; Hua, C.; Liu, C. Considerations for better construction and demolition waste management: Identifying the decision behaviors of contractors and government departments through a game theory decision-making model. J. Clean. Prod. 2019, 212, 190-199. [CrossRef] 
91. Mahpour, A.; Mortaheb, M.M. Financial-Based Incentive Plan to Reduce Construction Waste. J. Constr. Eng. Manag. 2018, 144. [CrossRef]

92. Ding, Z.; Yi, G.; Tam, V.W.Y.; Huang, T. A system dynamics-based environmental performance simulation of construction waste reduction management in China. Waste Manag. 2016, 51, 130-141. [CrossRef] [PubMed]

93. Mahamid, I. Impact of rework on material waste in building construction projects. Int. J. Constr. Manag. 2020. [CrossRef]

94. Wu, Z.; Yu, A.T.; Shen, L. Investigating the determinants of contractor's construction and demolition waste management behavior in Mainland China. Waste Manag. 2017, 60, 290-300. [CrossRef]

95. Long, H.; Liu, H.; Li, X.; Chen, L. An evolutionary game theory study for construction and demolition waste recycling considering green development performance under the chinese government's reward-penalty mechanism. Int. J. Environ. Res. Public Health 2020, 17, 6303. [CrossRef]

96. Su, Y. Multi-agent evolutionary game in the recycling utilization of construction waste. Sci. Total Environ. 2020, 738. [CrossRef]

97. Lu, W.; Yuan, H. A framework for understanding waste management studies in construction. Waste Manag. 2011, 31, 1252-1260. [CrossRef]

98. Ding, T.; Xiao, J. Estimation of building-related construction and demolition waste in Shanghai. Waste Manag. 2014, 34, 2327-2334. [CrossRef]

99. Li, Y.; Zhang, X.; Ding, G.; Feng, Z. Developing a quantitative construction waste estimation model for building construction projects. Resour. Conserv. Recycl. 2016, 106, 9-20. [CrossRef]

100. Maués, L.M.F.; Nascimento, B.D.M.O.D.; Lu, W.; Xue, F. Estimating construction waste generation in residential buildings: A fuzzy set theory approach in the Brazilian Amazon. J. Clean. Prod. 2020, 265. [CrossRef]

101. Li, H.; Chen, Z.; Wong, C.T.C. Barcode technology for an incentive reward program to reduce construction wastes. Comput. Aided Civ. Infrastruct. Eng. 2003, 18, 313-324. [CrossRef]

102. Li, H.; Chen, Z.; Yong, L.; Kong, S.C.W. Application of integrated GPS and GIS technology for reducing construction waste and improving construction efficiency. Autom. Constr. 2005, 14, 323-331. [CrossRef]

103. Wang, J.; Wu, H.; Duan, H.; Zillante, G.; Zuo, J.; Yuan, H. Combining life cycle assessment and Building Information Modelling to account for carbon emission of building demolition waste: A case study. J. Clean. Prod. 2018, 172, 3154-3166. [CrossRef]

104. Guerra, B.C.; Leite, F.; Faust, K.M. 4D-BIM to enhance construction waste reuse and recycle planning: Case studies on concrete and drywall waste streams. Waste Manag. 2020, 116, 79-90. [CrossRef]

105. Wu, H.; Wang, J.; Duan, H.; Ouyang, L.; Huang, W.; Zuo, J. An innovative approach to managing demolition waste via GIS (geographic information system): A case study in Shenzhen city, China. J. Clean. Prod. 2016, 112, 494-503. [CrossRef]

106. Paz, D.H.F.; Lafayette, K.P.V.; Sobral, M.C. GIS-based planning system for managing the flow of construction and demolition waste in Brazil. Waste Manag. Res. 2018, 36, 541-549. [CrossRef]

107. Seror, N.; Portnov, B.A. Identifying areas under potential risk of illegal construction and demolition waste dumping using GIS tools. Waste Manag. 2018, 75, 22-29. [CrossRef]

108. Bilal, M.; Oyedele, L.O.; Akinade, O.O.; Ajayi, S.O.; Alaka, H.A.; Owolabi, H.A.; Qadir, J.; Pasha, M.; Bello, S.A. Big data architecture for construction waste analytics (CWA): A conceptual framework. J. Build. Eng. 2016, 6, 144-156. [CrossRef]

109. Lu, W. Big data analytics to identify illegal construction waste dumping: A Hong Kong study. Resour. Conserv. Recycl. 2019, 141, 264-272. [CrossRef]

110. Chen, X.; Lu, W. Identifying factors influencing demolition waste generation in Hong Kong. J. Clean. Prod. 2017, 141, 799-811. [CrossRef]

111. Zhang, L.; Atkins, A.S. A Decision Support Application in Tracking Construction Waste Using Rule-based Reasoning and RFID Technology. Int. J. Comput. Intell. Syst. 2015, 8, 128-137. [CrossRef]

112. Wang, Z.; Li, H.; Zhang, X. Construction waste recycling robot for nails and screws: Computer vision technology and neural network approach. Autom. Constr. 2019, 97, 220-228. [CrossRef]

113. Yu, B.; Wang, J.; Li, J.; Zhang, J.; Lai, Y.; Xu, X. Prediction of large-scale demolition waste generation during urban renewal: A hybrid trilogy method. Waste Manag. 2019, 89, 1-9. [CrossRef]

114. Tam, V.W.Y.; Soomro, M.; Evangelista, A.C.J. A review of recycled aggregate in concrete applications (2000-2017). Constr. Build. Mater. 2018, 172, 272-292. [CrossRef]

115. Taffese, W.Z. Suitability investigation of recycled concrete aggregates for concrete production: An experimental case study. Adv. Civ. Eng. 2018, 2018. [CrossRef]

116. Lu, J.X.; Zhou, Y.; He, P.; Wang, S.; Shen, P.; Poon, C.S. Sustainable reuse of waste glass and incinerated sewage sludge ash in insulating building products: Functional and durability assessment. J. Clean. Prod. 2019, 236. [CrossRef]

117. Gangolells, M.; Casals, M.; Forcada, N.; Macarulla, M. Analysis of the implementation of effective waste management practices in construction projects and sites. Resour. Conserv. Recycl. 2014, 93, 99-111. [CrossRef]

118. Nikmehr, B.; Reza Hosseini, M.; Rameezdeen, R.; Chileshe, N.; Ghoddousi, P.; Arashpour, M. An integrated model for factors affecting construction and demolition waste management in Iran. Eng. Constr. Archit. Manag. 2017, 24, 1246-1268. [CrossRef]

119. Dosal, E.; Coronado, M.; Muñoz, I.; Viguri, J.R.; Andrés, A. Application of Multi-Criteria decision-making tool to locate construction and demolition waste (C\&DW) recycling facilities in a northern Spanish region. Environ. Eng. Manag. J. 2012, 11, 545-556. [CrossRef] 
120. Mousavi, M.; Ventura, A.; Antheaume, N. Decision-based territorial life cycle assessment for the management of cement concrete demolition waste. Waste Manag. Res. 2020. [CrossRef]

121. Hu, Q.; Peng, Y.; Guo, C.; Cai, D.; Su, P. Dynamic incentive mechanism design for recycling construction and Demolition waste under dual information asymmetry. Sustainability 2019, 11, 2943. [CrossRef]

122. Ghaffar, S.H.; Burman, M.; Braimah, N. Pathways to circular construction: An integrated management of construction and demolition waste for resource recovery. J. Clean. Prod. 2020, 244. [CrossRef]

123. Hoang, N.H.; Ishigaki, T.; Kubota, R.; Tong, T.K.; Nguyen, T.T.; Nguyen, H.G.; Yamada, M.; Kawamoto, K. Waste generation, composition, and handling in building-related construction and demolition in Hanoi, Vietnam. Waste Manag. 2020, $117,32-41$. [CrossRef] [PubMed]

124. Shooshtarian, S.; Caldera, S.; Maqsood, T.; Ryley, T. Using Recycled Construction and Demolition Waste Products: A Review of Stakeholders' Perceptions, Decisions, and Motivations. Recyclle 2020, 5, 31. [CrossRef]

125. Oyedele, L.O.; Ajayi, S.O.; Kadiri, K.O. Use of recycled products in UK construction industry: An empirical investigation into critical impediments and strategies for improvement. Resour. Conserv. Recycl. 2014, 93, 23-31. [CrossRef]

126. Tam, V.W.Y.; Kotrayothar, D.; Loo, Y.C. On the prevailing construction waste recycling practices: A South East Queensland study. Waste Manag. Res. 2009, 27, 167-174. [CrossRef]

127. Newaz, M.T.; Davis, P.; Sher, W.; Simon, L. Factors affecting construction waste management streams in Australia. Int. J. Constr. Manag. 2020. [CrossRef]

128. Liu, J.; Gong, E.; Wang, D.; Lai, X.H.; Zhu, J. Attitudes and behaviour towards construction waste minimisation: A comparative analysis between China and the USA. Environ. Sci. Pollut. Res. 2019, 26, 13681-13690. [CrossRef]

129. Sezer, A.A.; Bosch-Sijtsema, P. Actor-to-actor tensions influencing waste management in building refurbishment projects: A service ecosystem perspective. Int. J. Constr. Manag. 2020. [CrossRef]

130. Jain, S.; Singhal, S.; Jain, N.K.; Bhaskar, K. Construction and demolition waste recycling: Investigating the role of theory of planned behavior, institutional pressures and environmental consciousness. J. Clean. Prod. 2020, 263. [CrossRef]

131. Li, J.; Zuo, J.; Cai, H.; Zillante, G. Construction waste reduction behavior of contractor employees: An extended theory of planned behavior model approach. J. Clean. Prod. 2018, 172, 1399-1408. [CrossRef]

132. Venugopal, K.; Ambatipudi, A. The human resource (HR) factor and the impact of construction and demolition (C\&D) waste on environment: An integrated remedial method. Int. J. Recent Technol. Eng. 2019, 8, 535-538. [CrossRef]

133. Hao, J.L.; Hill, M.J.; Shen, L.Y. Managing Construction Waste On-site through System Dynamics Modelling: The Case of Hong Kong; Emerald Group Publishing Limited: Hong Kong, China, 2008.

134. Ekanayake, L.L.; Ofori, G. Building waste assessment score: Design-based tool. Build. Environ. 2004, 39, 851-861. [CrossRef]

135. Kpamma, E.Z.; Adjei-Kumi, T. Management of Waste in the Building Design Process: The Ghanaian Consultants' Perspective. Arch. Eng. Des. 2011, 7, 102-112. [CrossRef]

136. Baldwin, A.; Poon, C.S.; Shen, L.Y.; Austin, S.; Wong, I. Designing out waste in high-rise residential buildings: Analysis of precasting methods and traditional construction. Renew. Energy 2009, 34, 2067-2073. [CrossRef]

137. Poon, C.S.; Yu, A.T.W.; Jaillon, L. Reducing building waste at construction sites in Hong Kong. Constr. Manag. Econ. 2004, 22, 461-470. [CrossRef]

138. Luangcharoenrat, C.; Intrachooto, S.; Peansupap, V.; Sutthinarakorn, W. Factors influencing construction waste generation in building construction: Thailand's perspective. Sustainability 2019, 11, 3638. [CrossRef]

139. Akinade, O.O.; Oyedele, L.O.; Ajayi, S.O.; Bilal, M.; Alaka, H.A.; Owolabi, H.A.; Arawomo, O.O. Designing out construction waste using BIM technology: Stakeholders' expectations for industry deployment. J. Clean. Prod. 2018, 180, 375-385. [CrossRef]

140. Wang, J.; Yu, B.; Tam, V.W.Y.; Li, J.; Xu, X. Critical factors affecting willingness of design units towards construction waste minimization: An empirical study in Shenzhen, China. J. Clean. Prod. 2019, 221, 526-535. [CrossRef]

141. Doust, K.; Battista, G.; Rundle, P. Front-end construction waste minimization strategies. Aust. J. Civ. Eng. 2020. [CrossRef]

142. Teo, M.M.M.; Loosemore, M. A theory of waste behaviour in the construction industry. Constr. Manag. Econ. $2001,19,741-751$. [CrossRef]

143. Sezer, A.A. Factors influencing building refurbishment site managers' waste management efforts. J. Facil. Manag. 2017, 15, 318-334. [CrossRef]

144. Begum, R.A.; Siwar, C.; Pereira, J.J.; Jaafar, A.H. Attitude and behavioral factors in waste management in the construction industry of Malaysia. Resour. Conserv. Recycl. 2009, 53, 321-328. [CrossRef]

145. Li, J.; Zuo, J.; Jiang, W.; Zhong, X.; Li, J.; Pan, Y. Policy instrument choice for construction and demolition waste management: The case study of Shenzhen, China. Eng. Constr. Archit. Manag. 2020, 27, 1283-1297. [CrossRef]

146. Lu, W.; Lee, W.M.W.; Bao, Z.; Chi, B.; Webster, C. Cross-jurisdictional construction waste material trading: Learning from the smart grid. J. Clean. Prod. 2020, 277. [CrossRef]

147. Akhtar, A.; Sarmah, A.K. Construction and demolition waste generation and properties of recycled aggregate concrete: A global perspective. J. Clean. Prod. 2018, 186, 262-281. [CrossRef]

148. Warren, J.D.; Chong, W.K.; Kim, C. Recycling construction and demolition waste for construction in Kansas City metropolitan area, Kansas and Missouri. Transp. Res. Rec. J. Transp. Res. Board 2007, 193-200. [CrossRef] 
149. Yuan, H.; Shen, L.; Wang, J. Major obstacles to improving the performance of waste management in China's construction industry. Facilities 2011, 29, 224-242. [CrossRef]

150. Ling, F.Y.Y.; Nguyen, D.S.A. Strategies for construction waste management in Ho Chi Minh City, Vietnam. Built Environ. Proj. Asset Manag. 2013, 3, 141-156. [CrossRef]

151. Al-Hajj, A.; Hamani, K. Material waste in the UAE construction industry: Main causes and minimization practices. Arch. Eng. Des. 2011, 7, 221-235. [CrossRef]

152. Tam, V.W.Y.; Tam, C.M. Waste reduction through incentives: A case study. Build. Res. Inf. 2008, 36, 37-43. [CrossRef]

153. Wang, J.Y.; Kang, X.P.; Tam, V.W.Y. An investigation of construction wastes: An empirical study in Shenzhen. J. Eng. Des. Technol. 2008, 6, 227-236. [CrossRef]

154. Ling, F.Y.Y.; Lim, M.C.H. Implementation of a waste management plan for construction projects in Singapore. Archit. Sci. Rev. 2002, 45, 73-81. [CrossRef]

155. Ajayi, S.O.; Oyedele, L.O.; Akinade, O.O.; Bilal, M.; Owolabi, H.A.; Alaka, H.A.; Kadiri, K.O. Reducing waste to landfill: A need for cultural change in the UK construction industry. J. Build. Eng. 2016, 5, 185-193. [CrossRef]

156. Karunasena, G.; Amaratunga, D. Capacity gaps in post disaster construction \& demolition waste management. Eng. Constr. Archit. Manag. 2015, 22, 446-466. [CrossRef]

157. Bajjou, M.S.; Chafi, A. Identifying and Managing Critical Waste Factors for Lean Construction Projects. Eng. Manag. J. 2020, 32, 2-13. [CrossRef]

158. Laovisutthichai, V.; Lu, W.; Bao, Z. Design for construction waste minimization: Guidelines and practice. Arch. Eng. Des. 2020. [CrossRef]

159. Ajayi, S.O.; Oyedele, L.O.; Bilal, M.; Akinade, O.O.; Alaka, H.A.; Owolabi, H.A. Critical management practices influencing on-site waste minimization in construction projects. Waste Manag. 2017, 59, 330-339. [CrossRef]

160. Mendis, D.; Hewage, K.N.; Wrzesniewski, J. Reduction of construction wastes by improving construction contract management: A multinational evaluation. Waste Manag. Res. 2013, 31, 1062-1069. [CrossRef]

161. Mendis, D.; Hewage, K.N.; Wrzesniewski, J. Contractual obligations analysis for construction waste management in Canada. J. Civ. Eng. Manag. 2015, 21, 866-880. [CrossRef]

162. Saez, P.V.; Del Río Merino, M.; San-Antonio González, A.; Porras-Amores, C. Best practice measures assessment for construction and demolition waste management in building constructions. Resour. Conserv. Recycl. 2013, 75, 52-62. [CrossRef]

163. Wang, J.; Yuan, H.; Kang, X.; Lu, W. Critical success factors for on-site sorting of construction waste: A China study. Resour. Conserv. Recycl. 2010, 54, 931-936. [CrossRef]

164. Shen, L.Y.; Tam, V.W.Y.; Tam, C.M.; Drew, D. Mapping approach for examining waste management on construction sites. J. Constr. Eng. Manag. 2004, 130, 472-481. [CrossRef]

165. Li, M.; Yang, J. Critical factors for waste management in office building retrofit projects in Australia. Resour. Conserv. Recycl. 2014, 93, 85-98. [CrossRef]

166. Ajayi, S.O.; Oyedele, L.O.; Akinade, O.O.; Bilal, M.; Alaka, H.A.; Owolabi, H.A. Optimising material procurement for construction waste minimization: An exploration of success factors. Sustain. Mater. Technol. 2017, 11, 38-46. [CrossRef]

167. Ajayi, S.O.; Oyedele, L.O. Waste-efficient materials procurement for construction projects: A structural equation modelling of critical success factors. Waste Manag. 2018, 75, 60-69. [CrossRef]

168. Khanh, H.D.; Kim, S.Y. Development of waste occurrence level indicator in Vietnam construction industry. Eng. Constr. Archit. Manag. 2015, 22, 715-731. [CrossRef]

169. Cha, H.S.; Kim, J.; Han, J.Y. Identifying and assessing influence factors on improving waste management performance for building construction projects. J. Constr. Eng. Manag. 2009, 135, 647-656. [CrossRef]

170. Nahmens, I.; Ikuma, L.H. Effects of lean construction on sustainability of modular homebuilding. J. Archit. Eng. 2012, 18, 155-163. [CrossRef]

171. Tam, V.W.; Tam, C.M.; Zeng, S.; Ng, W.C. Towards adoption of prefabrication in construction. Build. Environ. 2007, 42, 3642-3654. [CrossRef]

172. Maqsoom, A.; Hashmi, A.A.Q.; Zeeshan, M.; Arshad, Q.; Nawaz, A.; Zeeshan, B.U.A.; Salahuddin, H. A system dynamics-based economic performance simulation of construction waste reduction management: Effective application of prefabrication. Environ. Eng. Manag. J. 2019, 18, 2363-2376. [CrossRef]

173. Jaillon, L.; Poon, C.S.; Chiang, Y.H. Quantifying the waste reduction potential of using prefabrication in building construction in Hong Kong. Waste Manag. 2009, 29, 309-320. [CrossRef]

174. Shan, M.; Hwang, B.-G. Green building rating systems: Global reviews of practices and research efforts. Sustain. Cities Soc. 2018, 39, 172-180. [CrossRef]

175. Esa, M.R.; Halog, A.; Rigamonti, L. Strategies for minimizing construction and demolition wastes in Malaysia. Resour. Conserv. Recycl. 2017, 120, 219-229. [CrossRef]

176. Zhang, X.; Wu, Y.; Shen, L. Application of low waste technologies for design and construction: A case study in Hong Kong. Renew. Sustain. Energy Rev. 2012, 16, 2973-2979. [CrossRef]

177. Poon, C.S.; Yu, A.T.W.; Ng, L.H. Comparison of low-waste building technologies adopted in public and private housing projects in Hong Kong. Eng. Constr. Archit. Manag. 2003, 10, 88-98. [CrossRef] 
178. Peres, S.; Loureiro, E.; Santos, H.; Silva, F.V.E.; Gusmao, A. The production of gaseous biofuels using biomass waste from construction sites in Recife, Brazil. Processes 2020, 8, 457. [CrossRef]

179. Hong, Y.; Wu, Y.R. Acidolysis as a biorefinery approach to producing advanced bioenergy from macroalgal biomass: A state-ofthe-art review. Bioresour. Technol. 2020, 318, 124080. [CrossRef]

180. Shanmugam, S.; Ngo, H.H.; Wu, Y.R. Advanced CRISPR/Cas-based genome editing tools for microbial biofuels production: A review. Renew. Energy 2020, 149, 1107-1119. [CrossRef] 